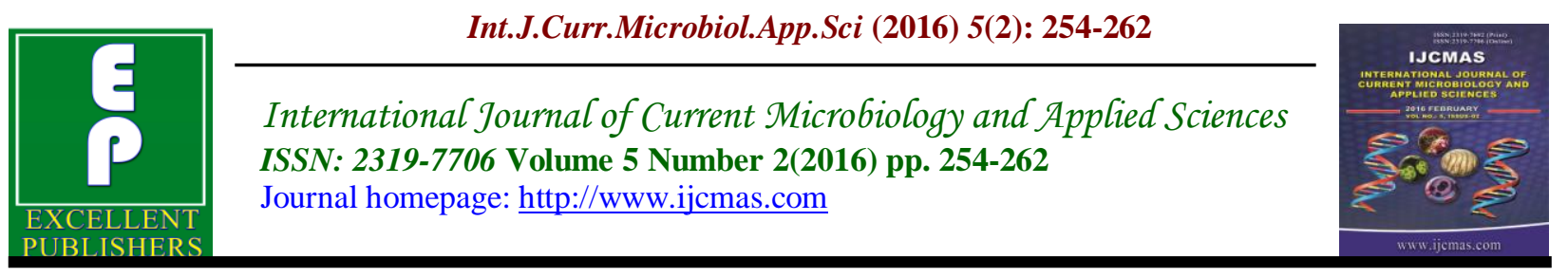

Original Research Article

doi: http://dx.doi.org/10.20546/ijcmas.2016.502.028

\title{
Production and Characterization of Exopolysaccharide produced By Oil Emulsifying Bacteria
}

\author{
Sheetal Sonawdekar and Arpita Gupte* \\ School of Biotechnology and Bioinformatics,D Y Patil University, Navi Mumbai, \\ Sector 15, Plot 50, CBD Belapur, Navi Mumbai-400 614, India \\ *Corresponding author
}

\begin{tabular}{|c|c|}
\hline & A B S T R A C T \\
\hline & \multirow{9}{*}{$\begin{array}{l}\text { Exopolysaccharides (EPS) are high molecular weight polymers consisting of sugar } \\
\text { residues which widely vary in structure and function. Many bacteria possess the } \\
\text { ability to synthesize and excrete exopolysaccharides. In the present study hundred } \\
\text { and twenty bacterial isolates were isolated from oil contaminated sites from in and } \\
\text { around Navi Mumbai and Thane districts of Maharashtra. Out of which } 19 \text { different } \\
\text { isolates were selected to explore the EPS production. These isolates were screened } \\
\text { for oil emulsification capacity using Emulsification Index } 24 \text { test. The isolates were } \\
\text { further tested for EPS production and optimization. The optimization was done for } \\
\text { different time durations ( } 24 \mathrm{~h} \text { to } 1 \text { week), nitrogen sources (Ammonium nitrate, } \\
\text { Sodium nitrate and Ammonium chloride) and pH. Culture } 1 \text { with the best EPS } \\
\text { producing capacity was identified as Bacillus cereus spp. The culture synthesized } \\
520 \mu \text { g/ml of EPS using } 0.5 \% \text { Sodium nitrate at pH } 7 \text { in } 48 \mathrm{~h} \text {. The FT-IR study } \\
\text { revealed the major bands corresponding to O-H, carboxylic acid and H- bonded } \\
\text { groups along with stretching of C-O, alcohol, ether and phenol groups. The } \\
\text { presence of EPS on the cell surface was confirmed using Scanning Electron } \\
\text { Microscopy. }\end{array}$} \\
\hline & \\
\hline $\mathrm{x}^{\mathrm{C}}$ & \\
\hline & \\
\hline & \\
\hline & \\
\hline & \\
\hline Al & \\
\hline & \\
\hline
\end{tabular}

\section{Introduction}

Many bacteria possess a natural ability to synthesize and excrete exopolysaccharides (EPS). They are also referred to as extracellular polysaccharides and exopolysaccharide materials.

These complex carbohydrates are found to be different in structure and function. While polysaccharides are the major component of bacterial EPS material, the EPS matrix also contains such non-sugar components as proteins and nucleic acids.
Bacterial exopolysaccharides are classified in two basic forms: capsular EPS and slime EPS. The classification is based on the degree of attachment with the cell surface. Outside the microbial cell, the EPS may be covalently linked to the cell surface, forming a capsule, or may remain unattached and exist as a loose slime. Most bacteria show a preference towards producing one form over the other (Vanhooren and Vandamme, 1998). 
EPS-producing bacteria are present in a variety of ecological niches. Therefore the physiological role of these exopolysaccharides is diverse and may be dependent on the specific natural habitat of the organism. Majorly they provide protection to the cells from environmental adversities such as desiccation, predation, and the effects of antibiotics. Bacterial exopolysaccharides mainly participate in such processes through microbial aggregation, surface attachment, biofilm formation, plant-microbe symbiosis, and environmental bioremediation. Furthermore, bacterial exopolysaccharides are emerging as a viable source of polymeric materials, and are being used as emulsifiers, stabilizers, binders, coagulants, and suspending agents in a variety of industries (Margaritis and Pace, 1985).

In the open environment bacteria are exposed to various petroleum contaminants which may induce exopolysaccharide production. Bacteria have designed strategic approaches to overcome the harsh effects of pollutants in the contaminated soil by producing exopolysaccharides or bioemulsifiers.

They can reduce the surface tension, interfacial tension of bacteria and increase the cell surface hydrophobicity of bacteria thereby enhancing the dispersal, emulsification and degradation of hydrocarbon pollutants in the contaminated site (Al-Tahhan et al, 2000; Zhang and Miller, 1992; Yakimov et al, 1998). Microorganisms produce EPS to perform diverse functions such as biofilm formation (Kreft and Wimpenny, 2001), tolerance to hydrocarbons (Aizawa et al, 2005), cryoprotectants (Kim and Yim, 2007), shield against antimicrobials (Kumon et al, 1994), aggregation (Adav and Lee, 2008), biofouling (Jain et al, 2007) and bioleaching of metals (Michel et al, 2009).
The present study aims to screen the EPS producing bacteria isolated from petroleum contaminated sites along with the optimization and characterization of exopolysaccharides by these isolates.

\section{Materials and Methods}

\section{Collection of Samples}

Soil samples from the different oil contaminated sites in and around Navi Mumbai were collected in sterile (st.) plastic bags. The samples duly labelled were stored at $-4^{\circ} \mathrm{C}$ for further analysis. The four stroke engine oil was obtained from the local petrol pump.

\section{Isolation of Microorganisms}

Soil sample (1.0g) was aseptically suspended in $9.0 \mathrm{ml}$ of the st. saline and vortexed. The soil particles were allowed to settle and the supernatant was used as inoculum to inoculate $100 \mathrm{ml}$ st. BushnellHass $(\mathrm{BH})$ broth and st. Nutrient broth (NB) with $2 \% \mathrm{v} / \mathrm{v}$ engine oil. The $\mathrm{BH}$ broth contained Magnesium Sulfate $0.2 \mathrm{~g} / \mathrm{l}$, Calcium Chloride 0.02g/l, Monopotassium Phosphate 1.0g/l, Dipotassium Phosphate $1.0 \mathrm{~g} / \mathrm{l}$, Ammonium Nitrate $1.0 \mathrm{~g} / \mathrm{l}$ and Ferric Chloride $0.05 \mathrm{~g} / \mathrm{l}$, Agar agar 25g and distilled water $1000 \mathrm{ml}$. The flasks were incubated on rotary shaker at $100 \mathrm{rpm}, 37^{\circ} \mathrm{C}$ for 1 week. Two subculturings were done with the same media with 2\% oil (Joshi and Pandey, 2011; Mittal and Singh, 2009).

\section{Screening of Oil Degrading Bacteria}

After second subculturing oil degrading microorganisms were isolated on st. $\mathrm{BH}$ agar plate over layed with $0.1 \mathrm{ml}$ oil. The plates were incubated at $37^{\circ} \mathrm{C}$ for 24 hours to 1 week in an incubator. The pure isolates obtained were preserved on st. nutrient agar 
slants. Screening of petroleum degrading isolate was carried out by growing the isolates in $50 \mathrm{ml}$ nutrient broth and BushnellHass $(\mathrm{BH})$ broth over layed with $2 \%$ v/v oil. Their ability to tolerate the oil content was accessed by measuring the turbidity using absorbance at 540 $\mathrm{nm}$.

\section{Emulsification Index}

The emulsification index (EI24) of culture samples was determined by adding $2 \mathrm{ml}$ of oil to the same amount of culture media. The contents were mixed for $2 \mathrm{~min}$ and were allowed to stand for 24 hours. The EI24 is given as percentage of height of emulsified layer $(\mathrm{mm})$ divided by total height of the liquid column (mm) (Bredholt et al, 1998; Desai and Banat, 1997; Lin and Ganesh, 2009).

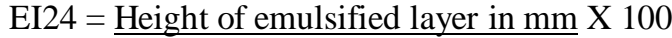 Height of the total layer in $\mathrm{mm}$}

(Eq. 1)

\section{Morphological and Physiological Characteristics}

The isolated bacteria were characterized and identified by their morphological characteristics based on size, shape and colony morphology on nutrient agar plate (Bergey et al, 1974). All isolates were examined by Gram staining. The best oil emulsifying and oil degrading culture was identified using 16s RNA sequencing.

\section{Extraction of Exopolysaccharides}

Sterile Bushnell and Hass Broth and nutrient broth $50 \mathrm{ml}$ each were inoculated with pure bacterial cultures under aseptic conditions. The medium was over layed with $1 \mathrm{ml}(2 \%$ $\mathrm{v} / \mathrm{v})$ engine oil. The flasks were kept for incubation at $37^{\circ} \mathrm{C}$ from $24 \mathrm{~h}$ to $168 \mathrm{~h}$. After incubation time $10 \mathrm{ml}$ medium along with cells was incubated in boiling water bath for
30 min to remove the surface bound exopolysaccharides. The broth was centrifuged at $9000 \mathrm{rpm}$ for $15 \mathrm{~min}$. The supernatant was mixed with double the volume of chilled ethanol and the mixture was incubated at $-20^{\circ} \mathrm{C}$ overnight. The precipitate of EPS thus formed was separated by centrifugation at $9000 \mathrm{rpm}$, $4^{\circ} \mathrm{C}$.

The protein content of the EPS was separated by precipitating it with $25 \%(\mathrm{w} / \mathrm{v})$ trichloroacetic acid on ice for $2 \mathrm{~h}$. The reprecipitation of EPS was carried out by addition of two volumes of ice cold ethanol. The precipitate was dried overnight at $70^{\circ} \mathrm{C}$. This precipitate was dissolved in hot $\mathrm{D} / \mathrm{W}$ and further used for the estimation of exopolysaccharide quantity(Al- Nahas and Darwish et al, 2011; Edward et al, 2011; Orsod et al, 2012).

\section{Estimation of Exopolysaccharides}

Exopolysaccharides were estimated as total carbohydrates by phenol-sulphuric acid method (Dubois et al, 1956). To $1 \mathrm{ml}$ of sample, $1 \mathrm{ml} 5 \%(\mathrm{w} / \mathrm{v})$ phenol was added followed by $5 \mathrm{ml}$ concentrated sulphuric acid. The sample tubes were kept in ice while adding sulphuric acid. The mixture was incubated at room temperature for 20 min and the absorbance was read at $490 \mathrm{~nm}$. Glucose was used as the standard in the range of $0-100 \mu \mathrm{g}$ concentration. A standard graph was plotted with absorbance at 490 $\mathrm{nm}$ against concentration of glucose.

\section{Optimization of Exopolysaccharide Production}

The exopolysaccharide production was optimized using three parameters i.e. time, nitrogen source with varying concentration and $\mathrm{pH}$. Sodium nitrate, Ammonium chloride and Ammonium nitrate were used as different nitrogen sources. The varying 
concentrations used were $0.1,0.5$ and $1 \%$ of each nitrogen source and denoted as a1= $0.01 \% \mathrm{NaNO}_{3}, \mathrm{a} 2=0.1 \% \mathrm{NaNO}_{3}, \mathrm{a} 3=0.5 \%$ $\mathrm{NaNO}_{3}, \quad \mathrm{~b} 1=0.01 \% \quad \mathrm{NH}_{4} \mathrm{Cl}, \quad \mathrm{b} 2=0.1 \%$ $\mathrm{NH}_{4} \mathrm{Cl}, \quad \mathrm{b} 3=0.5 \% \quad \mathrm{NH}_{4} \mathrm{Cl}, \quad \mathrm{c} 1=0.01 \%$ $\mathrm{NH}_{4} \mathrm{NO}_{3}, \mathrm{c} 2=0.1 \% \quad \mathrm{NH}_{4} \mathrm{NO}_{3}, \mathrm{c} 3=0.5 \%$ $\mathrm{NH}_{4} \mathrm{NO}_{3}$.

\section{FT-IR Analysis}

The EPS was characterized by using a Fourier Transform Infrared Spectrometer (PerkinElmer Spectrum Version 10.03.06). One part of EPS extract was mixed with ninety nine parts of dried potassium bromide $(\mathrm{KBr})$ separately and then compressed to prepare a salt disc of $3 \mathrm{~mm}$ diameter. These discs were subjected to IR- spectra measurement in the frequency range of 400 and $4000 \mathrm{~cm}^{-1}$.

\section{Scanning Electron Microscopy}

Scanning electron microscopy (SEM) was done to study the surface morphology of EPS producing Bacillus culture. Nutrient broth with (test) and without (control) oil were inoculated with log phase cultures. The broths were kept under shaking condition (120rpm) at $25^{\circ} \mathrm{C}\left( \pm 2{ }^{\circ} \mathrm{C}\right) .1 .5 \mathrm{ml}$ of late $\log$ phase cultures were centrifuged at $10,000 \mathrm{rpm}$ for $10 \mathrm{~min}$. The pellet obtained was washed twice with phosphate buffered saline and fixed in $2.5 \%$ glutaraldehyde in double distilled water (DDW) for $2 \mathrm{~h}$.

Fixed cells were washed twice with DDW and were subsequently dehydrated with series of ethanol from $25 \%$ to $100 \%$ for $5 \mathrm{~min}$ each and left to dry overnight in a desiccator. The specimens were mounted onto the sample holder with carbonconductive adhesive tapes and coated with gold using a sputter coater (Auto fine coater JFC-1600, JEOL) prior to viewing using a field-emission scanning electron microscope (FESEM JSM-7600F, JEOL).

\section{Results and Discussion}

A total of 19 hydrocarbon-utilizing microorganisms were isolated from the contaminated soil after the enrichment process. Seven isolates were found to be Gram-positive spore forming rods and the remaining isolates were Gram-negative rods. These isolates were screened using oil emulsification index. Results for the same are shown in Fig. 1.It showed that all isolates have a good potential to emulsify the oil. They expressed the oil emulsification index from 3-54\%. Culture 17 had the least emulsification index $(3 \%)$ whereas culture 1 had a highest percentage of emulsification i.e $54 \%$.

The isolates those expressed the higher oil emulsification capacity were used for the EPS production. The isolates 1, 3, 6, 7, 8 produced the EPS above $60 \mu \mathrm{g} / \mathrm{ml}$ and were chosen for the further study. All the extracted EPS samples were tested for their oil emulsification capacity. The results are shown in Fig. 2-a and 2-b.

EPS production was optimized for all the shortlisted cultures from $0 \mathrm{~h}$ to $168 \mathrm{~h}$. The maximum production was given by culture 1 i.e $186.66 \pm 3.5 \mu \mathrm{g} / \mathrm{ml}$ in $48 \mathrm{hrs}$ (Fig. 3).

Out of the three nitrogen sources used, sodium nitrate at $0.5 \%$ concentration provided the maximum yield for culture 1,3 and 8 within $48 \mathrm{~h}$ (Table 1). For culture 6 and $7,0.1 \%$ Sodium nitrate and $0.5 \%$ ammonium nitrate gave better EPS production respectively. So a3 was chosen as the nitrogen source for the further study. EPS production was optimized in the range of pH 5-9 for culture 1, 3, 8. For all the three cultures $\mathrm{pH} 7$ was found to be the most suitable pH (Fig. 4).

From the results of the optimization study, culture 1 was identified as the better culture 
for EPS production. For the structural analysis of EPS FT-IR technique was used. EPS was produced using optimized medium. The FT-IR analysis provided the results as shown in the Fig. 5.

Sharp band at 2900-3000 cm-1 strongly suggests a presence of broad stretching of $\mathrm{O}-\mathrm{H}$, carboxylic acid and $\mathrm{H}-$ bonded groups. The peak at $1000-1100 \mathrm{~cm}-1$ corresponds to stretching of C-O, alcohol, ether and phenol groups. Culture 1 was also studied through
SEM to detect the EPS layer over the surface. The cells were observed at 5000x and 10000x magnification. The control cells gave a very sharp appearance as compared to the cells grown in the presence of oil. The cells grown with oil appeared bulkier with a layer of exopolysaccharide over the surface (Fig. 6).

The culture 1 was identified as Bacillus cereus using biochemical and molecular identification.

Table.1 Comparison of EPS Production at 48 h using Different Nitrogen Sources

\begin{tabular}{|l|l|l|l|l|l|}
\hline & cul 1 & cul 3 & cul 6 & cul 7 & cul 8 \\
\hline a1 & $40 \pm 2.5$ & $60 \pm 3.2$ & $6.66 \pm 0.5$ & $6.66 \pm 0.5$ & $126.66 \pm 4.2$ \\
\hline a2 & $100 \pm 3.8$ & $10 \pm 1.5$ & $\mathbf{1 0 6 . 6 6} \pm 2.2$ & $6.66 \pm 0.5$ & $60 \pm 1.5$ \\
\hline a3 & $\mathbf{5 2 0} \pm 2.6$ & $\mathbf{2 4 0} \pm 3.6$ & $120 \pm 2.9$ & $73.33 \pm 2.5$ & $\mathbf{4 0 6 . 6 6} \pm 2.5$ \\
\hline b1 & $153.33 \pm 3.5$ & $120 \pm 2.6$ & $40 \pm 2.5$ & $93.33 \pm 2.8$ & $186.66 \pm 3.8$ \\
\hline b2 & $66.66 \pm 2.8$ & $100 \pm 3.4$ & $93.33 \pm 2.0$ & $60 \pm 2.0$ & $173.32 \pm 3.9$ \\
\hline b3 & $26.66 \pm 2.5$ & $20 \pm 1.8$ & $20 \pm 1.5$ & $\mathbf{1 3 3 . 3 3} \pm 2.6$ & $6.66 \pm 1.0$ \\
\hline c1 & $6.66 \pm 2.6$ & $80 \pm 2.4$ & $33.33 \pm 1.2$ & $53.33 \pm 2.2$ & $40 \pm 2.0$ \\
\hline c2 & $193.33 \pm 3.5$ & $156 \pm 3.1$ & $95 \pm 2.6$ & $106.66 \pm 3.5$ & $103.33 \pm 3.4$ \\
\hline c3 & $240 \pm 4.5$ & $120 \pm 2.8$ & $73.33 \pm 2.5$ & $113.33 \pm 4.0$ & $86.66 \pm 2.8$ \\
\hline
\end{tabular}

Fig.1 Emulsification Index of Different Isolates

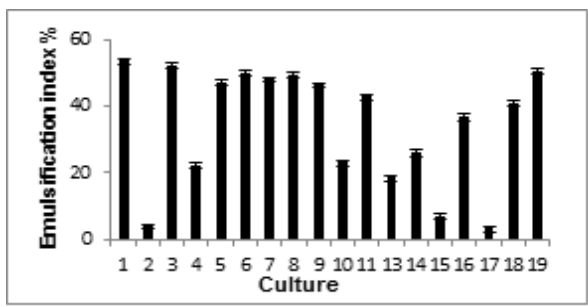

Fig.2a) Amount of Exopolysaccharide Produced b) EI 24 for Extracted Exopolysaccharide

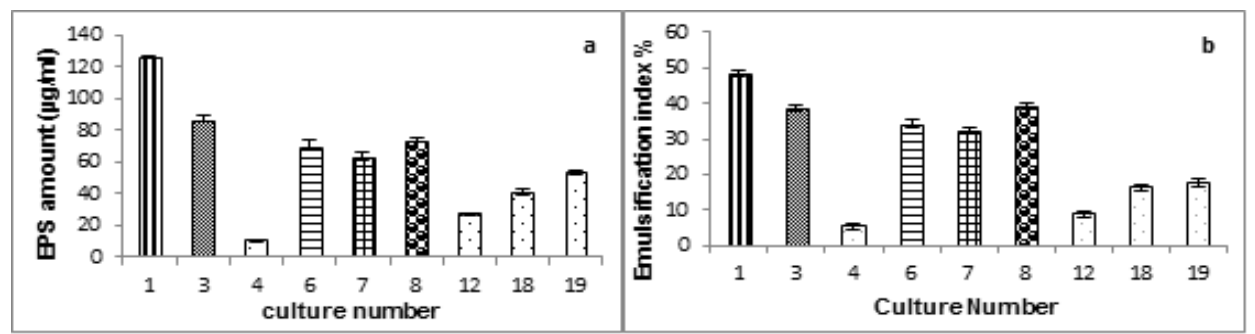


Fig.3 EPS Production at Different Intervals of Time

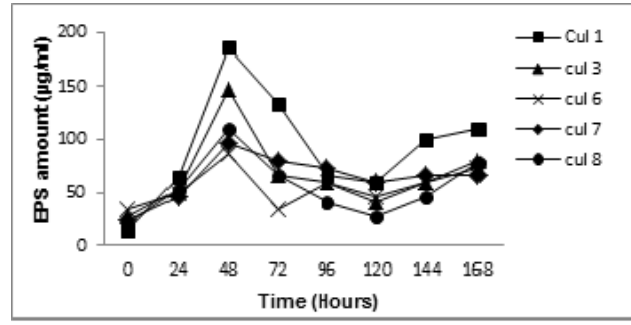

Fig.4 Comparison of FTIR Analysis for EPS Produced in Bushnell and Hass Broth+Oil and only Broth. (Blue line: NB without oil Green line: NB with oil)

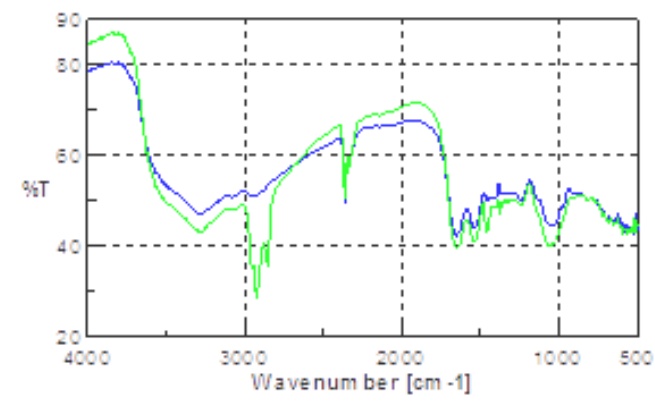

Fig.5 Effect of pH on EPS Production by a) Culture 1, b) Culture 3 and Culture 8

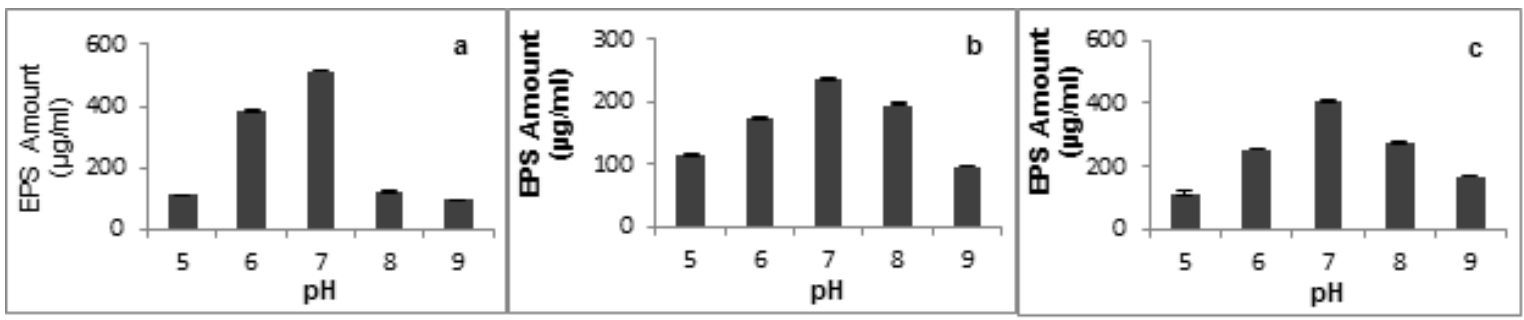

Fig.6 SEM of Cells Grown in Bushnell and Hass broth a) without oil (at 5000x), b) with Oil at $5000 x$

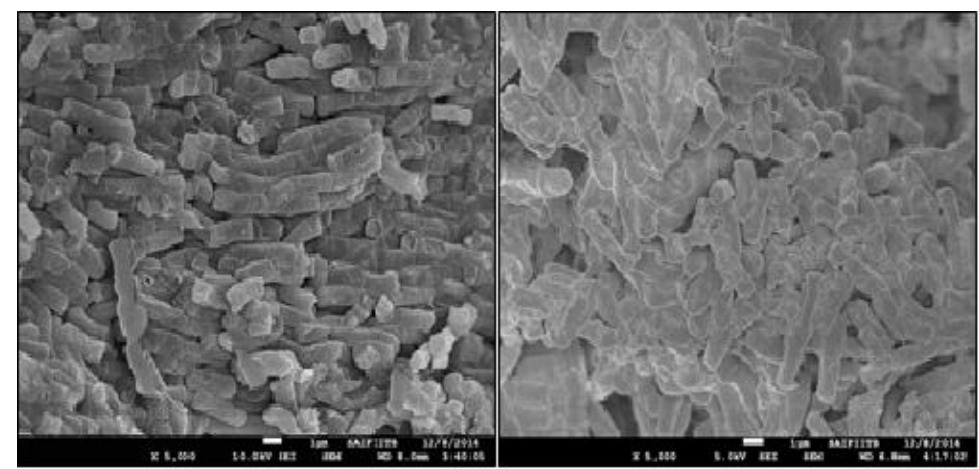


Microorganisms utilize a variety of organic compounds as the source of carbon and energy for their growth. Some microorganisms possess the ability to produce different types of bioactive compounds which also includes bioemulsifiers. These compounds help in emulsifying the oil. In the study undertaken by Murray et al it was shown that different bacteria express the oil emulsification capacity in the range of 0-80\% (Dorobantu et al, 2004). The culture 1 i.e. Bacillus cereus culture isolated during the present study showed 53\% emulsification.

The exopolysaccharide production was optimized under different environmental conditions. A wide variety of carbon sources can be used to produce microbial EPS. Many studies demonstrate the influence of the type of carbon source on EPSs production (Miquelet et al, 2010; Wang et $a l$, 2006). Similarly, Cerning et al. (Cerning et al, 1994) stated that the three growth conditions (temperature, $\mathrm{pH}$, and Carbon concentration) likely to affect EPS production. In the present study the engine oil was used as the only source of carbon for EPS production and optimization was done on three parameters like nitrogen source, time and $\mathrm{pH}$. The Bacillus cereus culture synthesized the maximum amount of EPS using $0.5 \%$ Sodium nitrate at $\mathrm{pH} 7$ in $48 \mathrm{hrs}$ $(520 \mu \mathrm{g} / \mathrm{ml})$. These results are in agreement with the findings of S. Bragadeeswaran (Bragadeeswaran et al, 2011) who has reported the EPS production using Bacillus cereus strain was in the range of $60.2 \mu \mathrm{g} / \mathrm{ml}$ to $521 \mu \mathrm{g} / \mathrm{ml}$.

The FT-IR study revealed the major bands corresponding to the presence of broad stretching of $\mathrm{O}-\mathrm{H}$, carboxylic acid and $\mathrm{H}-$ bonded groups along with stretching of $\mathrm{C}-\mathrm{O}$, alcohol, ether and phenol groups. Polysaccharides possessing carboxyl group is reported previously (Jindal et al, 2011; Patil et al, 2009).Absence of any broad stretching between 1500-1700 indicates the absence of proteins. Scanning Electron Microscopy made it very evident that the cell surface is covered with the EPS layer.

In conclusion, the present work provides evidence that Bacillus cereus can be useful in bioremediation of oil due to its oil emulsifying and EPS producing capacities.

\section{Acknowledgement}

We would like to thank SAIF labs, IIT Bombay for providing the GC-MS facility. We would also like to thank geneOmbio technologies, Pune; India for helping with identification of the culture.

\section{References}

Adav, S.S., Lee, D.J. 2008. Extraction of extracellular polymeric substances from aerobic granule with compact interior structure. J. Haz.Mat 154, $1120-1126$.

Aizawa, T., Neilan, B.A., Couperwhite, I., Urai, M., Anzai, H., Iwabuchi, N., Nakajima, M. and Sunairi, M.2005. Relationship between extracellular polysaccharide and benzene tolerance of Rhodococcus sp.Actinomyc 19(1), 1-6.

Al- Nahas, M.O, Darwish, M.M. et al. 2011. Characterization of an exopolysaccharide-producing marine bacterium, isolate Pseudoalteromonas Sp. AM, African Journal of Microbiology Research 5(22), 38233831.

Al-Tahhan, R.A., Sandrin, T.R., Bodour, A.A., Maier, R.M. 2000. Rhamnolipidinduced removal of lipopolysaccharide from Pseudomonas aeruginosa: effect on cell surface properties and 
interaction with hydrophobic substrates. Applied and Environmental Microbiology66(8), 3262-3268.

Bergey, D.H., Buchanan, R.E., Gibbons, N.E. 1974. Bergey's manual of determinative bacteriology. Baltimore, Williams \& Wilkins.

Bragadeeswaran, S., Jeevapriya, R., Prabhu, K., Sophia Rani, S., Priyadharsini, S., Balasubramanian, T. 2011. Exopolysaccharide production by Bacillus cereus GU812900, a fouling marine bacterium, African Journal of Microbiology Research 5(24), 41244132

Bredholt, H., Josefsen, K., Vatland, A., Bruheim, P., Eimhjellen, K. 1998. Emulsification of crude oil by an alkane-oxidizing rhodococcus species isolated from sea water. Canadian Journal of Microbiology 44, 330-340.

Cerning, J., Renard, C.M.G.C., Thibault, J.F., C. Buillanne, Landon, M., Desmazeaud, M., Topisirovic, L. 1994. Carbon source requirements for exopolysaccharide production by Lactobacillus casei CG11 and partial structure analysis of the polymer. Appl. Environ. Microbiol 60, 39143919.

Desai, J.D., Banat, I.M. 1997. Microbial production of surfactants and their commercial potential. Microbiology Molecular Biology Review 61, 47-64.

Dorobantu, L.S., Yeung, A.K.C., Foght, J.M., Gray, M.R. 2004. Stabilization of oil-water emulsions by hydrophobic bacteria. Applied and Environmental Microbiology 70(10), 6333-6336.

Dubois, M. Gilles, K.A., Hamilton, J.K., Rebers, P.A., Smith, F. 1956.Colorimetric method for determination of sugars and related substances. Analytical

Chemistry 28(3), 350-356.
Edward, A., Melchias, G., Prabhu, J.A., Wilson, A., Anbananthan, V., Sivaperumal, K. 2011. Detection of exopolysaccharides / bioemulsifier producing bacterial isolates from petroleum contaminated soil. International Journal of Biological Technology 2(2), 1-7.

Jain, A., Nishad, K.K., Bhosle, N.B. 2007. Effects of DNP on cell surface properties of marine bacteria and its implication for adhesion to surfaces. Biofoul 23(3-4), 171-177.

Jindal, N., Singh, DP., Khattar, J.I.S. 2011. Kinetics and physico-chemical characterization of exopolysaccharides produced by the cyanobacterium Oscillatoriaformosa. World J Microbiol. Biotechnol 27, 2139-2146. DOI 10.1007/s11274-011-0678-6.

Joshi, P.A., Pandey, G.B. 2011. Screening of petroleum degrading bacteria from cow dung. Research Journal of Agricultural Science 2(1), 69-71.

Kim, S.J., Yim, J.H. 2007. Cryoprotective properties of exopolysaccharide (P21653) produced by the Antarctic bacterium, Pseudoalteromonas arctica KOPRI 21653. J. Microbiol 45(6), 510-514.

Kreft, J.U., Wimpenny, J.W.T. 2001. Effect of EPS on biofilm structure and function as revealed by an individualbased model of biofilm growth. Water Sci. Technol 43, 135-141.

Kumon, H., Tomoshika, K., Matunaga, T., Ogawa, M., Ohmori, H.A. 1994. Sandwich cup method for the penetration assay of antimicrobial agents through

Pseudomonasexopolysaccharides. Microbiol. Immunol 38, 615- 619.

Lin, J. Ganesh, A. 2009.Diesel degradation and biosurfactant production by grampositive isolates. African Journal of Biotechnology 8 (21), 5847-5854. 
Margaritis, A., Pace, G.W. 1985. Microbial polysaccharides. In: comprehensive biotechnology. Moo-Young, M. (ed), Pergamon Press Ltd., Oxford, 10051044.

Michel, C., Beny, C., Delorme, F., Poirier, L., Spolaore, P., Morin, D., 'Hugues, P. 2009. New protocol for the rapid quantification of exopolysaccharides in continuous culture systems of acidophilic bioleaching bacteria. Appl.Microbiol. Biotechnol 82, 371378.

Miqueleto, A.P., Dolosic, C.C., Pozzi, E., Foresti, E., Zaiat, M. 2010. Influence of carbon sources and $\mathrm{C} / \mathrm{N}$ ratio on EPS production in anaerobic sequencing batch biofilm reactors for wastewater treatment. Bioresour Technol 101, 1324-1330.

Mittal, A., Singh, P. 2009. Isolation of hydrocarbon degrading bacteria from soils contaminated with oil spills. Indian Journal of Experimental Biology 47, 760-765.

Orsod, M., Joseph, M., Huyop, F. 2012. Characterization of exopolysaccharides produced by Bacillus cereus and Brachybacterium $S p$. isolated from Asian sea bass (Lates Calcarifer). Malaysian Journal of Microbiology 8(3), 170-174.
Patil, S.V., Bathe, G.A., Patil, A.V., Patil, R.H., Salunkea, R. 2009. Production of bioflocculant exopolysaccharide by Bacillus subtilis. Adv. Biotechnol 58, 15-16.

Vanhooren, P., Vandamme, E.J. 1998. Biosynthesis, physiological role, use and fermentation process characteristics of bacterial exopolysaccharides. Recent Research Developments in Fermentation and Bioengineering 1, 253-300.

Wang, X., Xu, P., Yuan, Y., Liu, C., Zhang, D. 2006. Modeling for gellan gum production by sphingomonas paucimobilis ATCC 31461 in a simplified medium. Appl Environ Microbiol 72, 3367-3374.

Yakimov, M.M., Golyshin, P.N., Lang, S., Moore, E.R.B., Abraham, W.R., Lunsdorf, H., Timmis, K.N. 1998. Alkanivorax borkumensis gen. nov., sp. nov., a new, hydrocarbondegrading and surfactant-producing marine bacterium. Int. J. Sys. Bacteriol 48, 339-348.

Zhang, Y., Miller, R.M. 1992. Enhanced octadecane dispersion and biodegradation by a Pseudomonas rhamnolipid surfactant (biosurfactant). Appl. Environ. Microbiol 58(10), 3276-3282.

\section{How to cite this article:}

Sheetal Sonawdekar and Arpita Gupte. 2016. Production and Characterization of Exopolysaccharide produced By Oil Emulsifying Bacteria. Int.J.Curr.Microbiol.App.Sci.5(2): 254-262. doi: http://dx.doi.org/10.20546/ijcmas.2016.502.028 